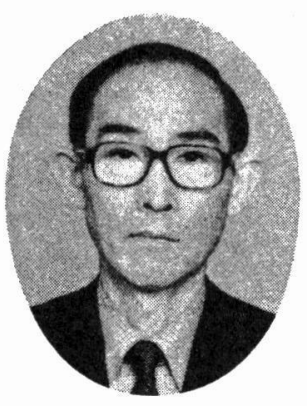

\title{
新年 のご挨拶
}

日本複合材料学会会長 北 條 英 光

平成 2 年の年頭にあたり, 会員の皆様に新年のお慶びを申し上げます.

昨年 4 月の理事会に拈さまして，小林繁夫前会長のあとを受けて平成元年・2 年度の会長に選出 されました，微力ではございますが，皆様のお力添觉を得まして，会の発展に力を尽すつもりでご ざいます.

早いもので, 日本複合材料学会も昭和 50 年に世界に先駆けて創設されましてから 15 年の歳月が 経過しようとして和ります.この間, 初代会長林毅先生をはじめ歴代の会長, 役員の方々のご努力 と会員の皆様のご協力とにより，また最近は 21 世紀の技術を支光推進する複合材料といら時代の 要請もあり，扣蔭さまで会も順調な発展の一途を辿って扣ります. 正会員数も 900 名に近く悲願の 1,000名も間近かになって参りました. 本会の活動も創設当初からの「月例研究会」,「複合材料シ ンポジゥムのほか, その後昭和 59 年に「複合材料セミナー」が, また昭和 60 年から強化プラス チック協会とジョイントで行う「JRP/C セミナー」も加わり, さらに昭和 63 年度からは年会に当 ります「研究発表講演会」が開催されるようになりまして, 本会の研究活動, 教育・啓蒙活動なら びに最新情報サービス活動も大学会のそれと比べても孫色のないものとなったわけでございます.

特に複合材料シンポジウムは月例研究会（木村脩七月例研委員長）と並び本会を代表する行事です が, 年々盛況になり活発な討論の場を提供しております. 研究発表講演会が 5 月の総会時に行わ れるよらになりました関係で, シンポジウムはなるべく東京以外でといらことになり，昭和 63 年 度は大阪，平成元年度（第 14 回）は 11 月 30, 31 日に金沢で開かれ，本年は 10 月 18,19 日に仙 台での開催を予定して打ります (金原勲行事委員長). 編集, 出版関係に括きましても，本会の 10 周年を機に邦文誌は季刊から隔月刊に增強され，現在は内容の一層の充実がはかられております (塩田一路邦文誌編集委員長)。また，本会の 15 周年を記念して企画された「複合材料ハンドブッ ク」が技術者, 研究者の座右の書として昨年 11 月末に日刊工業新聞社から出版されました (森田幹 郎出版委員長). 以上のような国内に打ける事業のほかに, 本会のような発展途上の学会としては 活発過ぎる国際交流を行い世界に貢献して参りました (小林昭国際交流委員長). 過去に, 第 4 回 国際複合材料会議 (ICCM-IV), 日ソ複合材料シンポジウム 2 回, 日中複合材料シンポジウム 2 回を てがけて拈り, 本年 6 月にはまた第 5 回日米複合材料会議が日本で開催されます.そして, 1993 年 の ICCM-IX は東京開催を目標に準備を進める予定であります。それまでには本会のかねてからの 目標でありました社団法人化（正会員 1,000 名以上，基金 2,000 万円以上）を達成するべく努力し たいと思って打ります (百島祐忠組織検討委員長). 会員の皆様には会員増強のため一層のご協力を いただきたく打願い申し上げます。

このように会は一応順調に推移して扣りますが，一つ残念なことは，従来年 2 回の予定で発行し 
て参りました欧文誌 Transactions of JSCM が，昨年 10 月に出ました Vol. 12, No. 1/2 合併号を 最後にピリオドを打ったことであります。しかしこれる，すでに邦文誌等でお知らせしております ように, 本会とオランダの VSP 社と共同で出版する予定の新しい欧文誌 International Transactions of JSCM, “Advanced Composite Materials”に生れかわるためであります.この国際誌 の編集には強化プラスチック協会のご協力もいただき，年 4 回の発行となります）今のところ，創 刊号は本年の春頃を予定しております (宮入裕夫欧文誌編集委員長). この新しい国祭誌の発行によ り，従来問題となっておりました海外におけるサーキュレーションの問題は大きく改善されること になります. Advanced Composite Materials が今後, 海外において活躍する本会の新しい顔とな りますので，会員の皆様にはこの新しい欧文誌に暖かいご支援とご協力を賜わりますようお願い申 し上げまして，新年のご挨拶とさせていただきます。 